\title{
HOW THE STUDENT'S PROBLEM SOLVING ON MATHEMATICS WITH MEANS ENDS ANALYSIS (MEA)
}

\author{
Ayu Apriliya Cinthyadewi ${ }^{1}$, Sanusi $^{2}$, Swasti Maharani ${ }^{3}$ \\ Program Studi Pendidikan Matematika, Universitas PGRI Madiun. Jalan Setiabudi No. 85, Madiun \\ E-mail: ayuapriliyaxiia5@gmail.com,Email: sanusi.mathedu@unipma.ac.id,Email: \\ swasti.mathedu@unipma.ac.id, Telp: +6285850849096
}

\begin{abstract}
Abstrak
Penelitian ini bertujuan untuk menganalisis kemampuan penyelesaian masalah matematika siswa SMP melalui pendekatan Means Ends Analysis (MEA). Tahapan pendekatan MEA meliputi identifikasi perbedaan antara Current State dan Goal State, organisasi Sub Goals dan pemilihan operator atau solusi. Jenis penelitian ini adalah penelitian deskriptif kualitatif. Subjek penelitian adalah enam siswa kelas VII SMP Negeri 3 Mejayan Kabupaten Madiun. Teknik pengambilan subjek penelitian yang digunakan adalah teknik purposive sampling. Teknik pengumpulan data dilakukan dengan metode tes, wawancara, dan dokumentasi. Teknik keabsahan data dilakukan dengan triangulasi teknik yaitu membandingkan data hasil tes dan data wawancara. Data hasil penelitian dianalisis melalui reduksi, penyajian data, penarikan kesimpulan dan verifikasi. Hasil penelitian ini adalah siswa kemampuan tinggi mampu mengidentifikasi dan memahami informasi penting dari permasalahan, mampu melakukan abstraksi, terampil mengoperasikan simbol matematika serta mampu menuliskan langkah penyelesaian dengan sistematis dan rinci. Siswa kemampuan sedang mampu mengidentifikasi dan menyelesaikan masalah namun belum sistematis menuliskan langkah penyelesaian. Siswa kemampuan rendah mampu menyelesaikan masalah namun tidak menuliskan langkah penyelesaian secara sistematis dan rinci serta tidak menuliskan kesimpulan. Penelitian ini dapat dikaji lebih lanjut untuk dijadikan Penelitian Tindakan Kelas (PTK) untuk meningkatkan kemampuan pemecahan masalah siswa.

\section{The Analysis of Students Mathematical Problem Solving ability throught Means Ends Analysis Approach}

\begin{abstract}
This research aims to analyze the problem solving ability of student through the Means Ends Analysis (MEA). The approach stages of the MEA model include identifying differences between Current State and Goal State, organization Sub Goals and selection of operators or solutions. The type of this research is descriptive qualitative research. The subjects were six students of class VII of SMP Negeri 3 Mejayan Madiun Regency. Technique of research subject taken is purposive sampling technique. Technique of collecting data is done by test method, interview, and documentation. Data validity technique is done by triangulation technique that is comparing test result data and interview data. The data of the research were analyzed by reduction, display of data, conclusion and verification. The conclusions of this research are high ability students able to identify and understand important information from problems, able to perform abstraction, skilled to operate mathematical symbol and able to write systematic and detailed settlement step. Students ability is being able to identify and resolve problems but not yet systematically write down the settlement steps. Low ability students can solve problems but do not write down the steps in a systematic and detailed settlement and do not write conclusions.
\end{abstract}

Keywords: Problem solving, Means Ends Analysis;Learning;Algebra 


\section{PENDAHULUAN}

Matematika memegang peranan penting dalam berbagai bidang khususnya pendidikan (Yahyawati, 2013; Yarmayani, 2016). Siswa sekolah dasar hingga sekolah menengah perlu diberikan pengajaran matematika untuk melatih mereka mengembangkan daya pikir (Juanda, Johar, \& Ikhsan, 2013). Sehingga siswa mampu berpikir logis, kritis, sistematis, kreatif dan analitis dalam menyelesaikan suatu permasalahan (Yarmayani, 2016). Ruang lingkup matematika yang diajarkan pada siswa sekolah menengah meliputi pengoperasian simbol-simbol, pengukuran, perhitungan, aritmetika, aljabar dan geometri (Delphie, 2009). Aljabar sebagai salah satu cabang ilmu matematika yang mempelajari operasi hitung bilangan serta hubungan antar bilangan yang diwujudkan dalam simbol huruf-huruf. Bentukbentuk permasalahan berkaitan tentang materi aljabar sering dikaitkan dengan permasalahan kehidupan sehari-hari, dimana permasalahan akan dimodifikasi dalam bentuk variabel huruf.

Siswa pertama kali mengenal materi aljabar ketika berada pada jenjang Sekolah Menengah Pertama (SMP). Pada kondisi ini siswa SMP berada pada masa remaja yaitu peralihan antara anak-anak ke dewasa (Kemendikbud, 2016). Sehingga pada fase ini mereka mengalami perkembangan yang signifikan baik fisik, kognitif serta emosionalnya. Meskipun pada fase ini siswa SMP sudah mampu memecahkan masalah abstrak namun pemikiran mereka masih kurang matang.

Berdasarkan hasil observasi terhadap siswa kelas VII SMP Negeri 3 Mejayan dan wawancara dengan guru matematika pada tanggal 07 April 2018. Guru matematika pada saat wawancara mengungkapkan bahwa kemampuan siswa dalam menyelesaikan masalah matematika khususnya aljabar masih kurang. Siswa ketika diminta untuk menentukan penyelesaian suatu soal matematika berkaitan dengan materi persamaan linier satu variabel cenderung tidak sesuai prosedur, langkah dan konsep penyelesaian yang tepat. Mereka cenderung menggunakan cara cepat dan terkadang sebagian siswa kurang memahami gambaran permasalahan yang dihadapi. Hal tersebut juga didukung pada penelitian sebelumnya yang menunjukkan hasil belajar siswa kelas VII SMP Negeri 1 Banda Aceh dalam materi bentuk aljabar masih sangat rendah yaitu 3,7\% dari 27 siswa yang dapat menguasai materi bentuk aljabar (Hasibuan, 2015).

Siswa SMP dituntut dapat menguasai kemampuan pemecahan masalah (Yarmayani, 2016). Kemampuan pemecahan masalah penting dikuasai siswa untuk menyelesaikan masalah matematika, khususnya masalah aljabar. Hal tersebut sesuai dengan salah satu tujuan pembelajaran matematika Indonesia diantaranya yaitu (1) memecahkan masalah yang meliputi kemampuan memahami masalah, merancang model dan menafsirkan solusi yang diperoleh, (2) mengkomunikasikan gagasan dengan simbol, tabel, diagram atau media lain untuk memperjelas keadaan atau masalah (Permendiknas, 2006).

Guru sebagai pembimbing siswa ketika berada di sekolah harus mampu mendukung dan mengidentifikasi potensi siswa guna memperlancar terjadinya proses pembelajaran (Kemendikbud, 2016). Guru harus mampu berperan aktif memotivasi serta memfasilitasi siswa dalam proses belajar mengajar di kelas. Salah satunya dengan menerapkan suatu pendekatan pembelajaran yang tepat dan sesuai dengan isi materi yang diajarkan kepada siswa. Pendekatan Means Ends Analysis (MEA) mampu menjadi solusi untuk mengatasi permasalahan rendahnya kemampuan pemecahan masalah siswa (Triyanti, 2017).

Pendekatan Means Ends Analysis (MEA) merupakan suatu pendekatan untuk menganalisis permasalahn melalui berbagai cara untuk mencapai tujuan akhir yang diinginkan (Muin, Permata, \& Afidah, 2014; Palupi, 2016; Riana \& Abdulkarim, 2017; Suyatno, 2009). Melalui pendekatan ini siswa dilatih untuk memahami suatu masalah kemudian menyusun rencana penyelesaian serta menemukan perbedaan hingga kemudian mampu menemukan cara mengurangi perbedaan yang ada untuk mencapai hasil akhir yang diinginkan. Penerapan pembelajaran melalui pendekatan Means Ends Analysis (MEA) ini siswa bukan hanya dinilai dari hasil akhir saja namun juga dilihat bagaimana tahapan serta proses dalam menemukan jawaban akhir yang diinginkan (Supendi, Jamiah, \& Ahmad, 2017). Hal tersebut juga didukung penelitian sebelumnya bahwa penerapan pendekatan Means Ends Analysis (MEA) dapat meningkatkan kemampuan siswa dalam pemecahan masalah matematika (Yahyawati, 2013). Sehingga dengan penerapan pendekatan Means Ends Analysis (MEA) ini mampu meningkatkan kemampuan pemecahan masalah matematika siswa (Hartini \& Lianti, 2015; Nugroho, Mahfud, \& Karsono, 2017).

Berdasarkan uraian diatas, maka penulis tertarik untuk mengkaji lebih lanjut tentang "Analisis Kemampuan Penyelesaian Masalah Matematika Siswa SMP melalui Pendekatan Means Ends Analysis (MEA)" 


\section{METODE}

Penelitian ini dilakukan di SMP negeri 3 Mejayan kelas VII C. Penelitian in dilaksanakan secara bertahap yaitu tahap persiapan, tahap ini meliputi pengajuan judul dan penyusunan proposal yang dilaksanakan pada bulan Maret 2018 hingga April 2018. Tahap pelaksanaan, pada tahap ini peneliti melakukan penelitian di lapangan yang dilaksanakan pada bulan Mei 2018. Tahap penulisan laporan, pada tahap ini meliputi analisis data dan penyusunan laporan hasil penelitian yang dilaksanakan mulai bulan Mei 2018 hingga Juli 2018. Jenis penelitian yang digunakan adalah pendekatan deskriptif kualitatif karena tujuan penelitian untuk menganalisis kemampuan penyelesaian masalah siswa melalui pendekatan MEA.

Penelitian dilakukan dengan menerapkan pendekatan MEA pada proses pembelajaran, selanjutnya pemberian tes dan wawancara terhadap subjek penelitian. Data yang dihasilkan berupa data deskriptif yang berupa data hasil tes tulis dan data wawancara. Sumber data pada penelitian ini adalah sumber primer berasal dari siswa kelas VII C SMP Negeri 3 Mejayan. Subjek dalam penelitian ini adalah 6 siswa kelas VII C SMP Negeri 3 Mejayan dimana subjek terdiri 2 orang siswa kemampuan tinggi, 2 orang siswa kemampuan sedang dan 2 orang siswa kemampuan rendah. Pengambilan subjek penelitian menggunakan teknik purposive sampling, yaitu berdasarkan nilai UAS Ganjil 2017/2018.

Teknik pengumpulan data dalam penelitian ini menggunakan tes berupa sebuah soal pemecahan masalah matematika dan metode wawancara. Peneliti menggunakan data hasil tes dan transkrip wawancara untuk disajikan dalam data penelitian. Data hasil tes dan hasil wawancara dibandingkan untuk mendapatkan data yang valid. Selanjutnya data penelitian yang sudah valid dianalisis berdasarkan tahap penyelesaian masalah melalui pendekatan MEA.

\section{HASIL DAN PEMBAHASAN}

Berdasarkan analisis kemampuan penyelesaian masalah matematika siswa melalui pendekatan MEA, peneliti akan memaparkan hasil dan pembahasan sebagi berikut.

\section{Subjek 1 (Kategori Kemampuan Tinggi)}

Berdasarkan analisis data tes dan hasil wawancara subjek 1 akan diuraikan pembahasan pada setiap langkah penyelesaian masalah matematika melalui pendekatan MEA sebagai berikut.

a. Tahap Identifikasi

Perbedaan antara

Current State dan Goal State

$\begin{aligned} & \text { Diketahui: Biaya Membuat Scbuah roti }=R p \cdot 1000 \\ & \text { Biaya gaji karyawan }=R p .750 \cdot 000 \\ & \text { Harga jual sebuah roti }=K \cdot 2.500 \\ & \text { Ditanga }=\text { Berapa banyak roti yang harus terjual tiap hari agar } \\ & \text { Pendapatan sama dengan pengeluaran? }\end{aligned}$

\section{Gambar 1}

Berdasarkan analisis hasil tes dan wawancara dari Gambar 1 subjek 1 mengerti isi soal yaitu mampu menuliskan apa yang diketahui dan apa yang ditanyakan sesuai apa isi soal. Sehingga subjek 1 tergolong mampu mengidentifikasi, menentukan dan memahami informasi penting dari permasalahan.

b. Tahap Organisasi Sub

Goals

$\begin{aligned} & \text { Jawab }= \text { Misal jumiah roti adalah }=y \\ & \text { Model matematika }= \\ & \text { pendapatan }=\text { pengeluarah } \\ & \text { 1.50-000+ } 1000 \text { y }=2.500 \text { y. }\end{aligned}$

\section{Gambar 2}

Berdasarkan analisis hasil tes dan wawancara dari Gambar 2 subjek 1 mampu membuat permisalan dan menuliskan model matematika dari soal. Sehingga subjek 1 tergolong mampu melakukan abstraksi dan menerjemahkan masalah persamaan linier satu variabel ke dalam kalimat/model matematika.

c. Tahap Pemilihan Operator atau Solusi

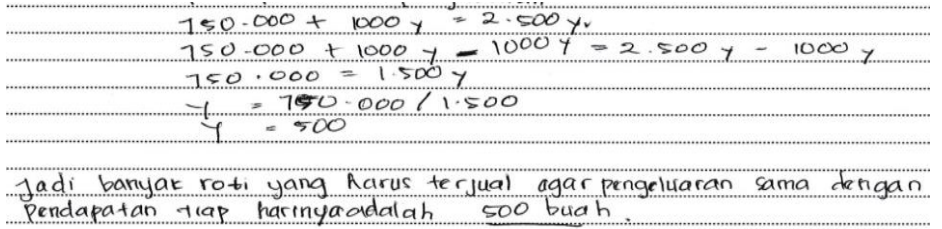

Gambar 3

Berdasarkan analisis hasil tes dan wawancara dari Gambar 3 subjek 1 mampu menyelesaikan masalah dengan menambahkan suatu bilangan ke masing-masing ruas 
selanjutnya menyederhanakan variabel y. Kemudian subjek 1 mampu membuat dan menuliskan kesimpulan sesuai apa yang ditanyakan pada soal. Sehingga subjek 1 tergolong mampu mengoperasikan simbol-simbol matematika untuk menyelesaikan masalah persamaan linier satu variabel.

Dari beberapa uraian diatas sesuai dengan penelitian Eviliyanida bahwa siswa yang dapat memahami masalah akan terampil dalam memilih dan mengidentifikasi kondisi serta konsep yang relevan untuk mencari generalisasi dan merumuskan penyelesaian masalah (Eviliyanida, 2010).

\section{Subjek 2 (Kategori Kemamapuan Tinggi)}

Berdasarkan analisis data tes dan hasil wawancara subjek 2 akan diuraikan pembahasan pada setiap langkah penyelesaian masalah matematika melalui pendekatan model MEA sebagai berikut.

a. Tahap Identifikasi

Perbedaan antara

Current State dan Goal

State

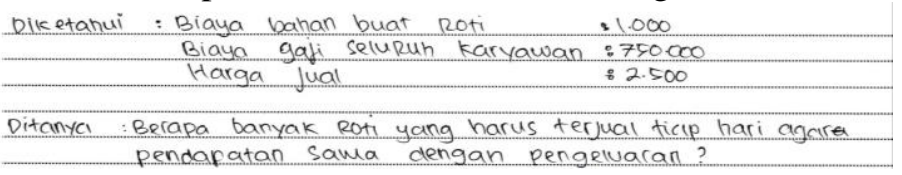

Gambar 4

Berdasarkan analisis data tes dan wawancara dari Gambar 4 subjek 2 mampu menuliskan apa yang diketahui dan apa yang ditanyakan sesuai dengan isi soal. Sehingga subjek 2 tergolong mampu mengidentifikasi, menentukan dan memahami informasi penting dari permasalahan.

b. Tahap Organisasi Sub Goals

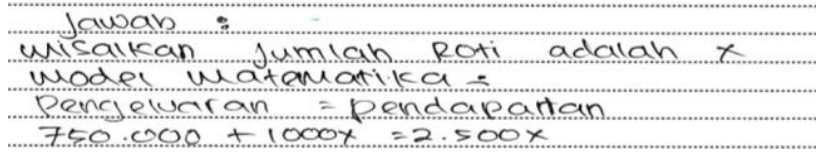

Gambar 5

Berdasarkan analisis hasil tes dan wawancara dari Gambar 5 subjek 2 mampu membuat permisalan dan menuliskan model matematika. Sehingga subjek 2 tergolong mampu melakukan abstraksi dan menerjemahkan masalah persamaan linier satu variabel ke dalam kalimat/model matematika.

c. Tahap Pemilihan Operator atau Solusi

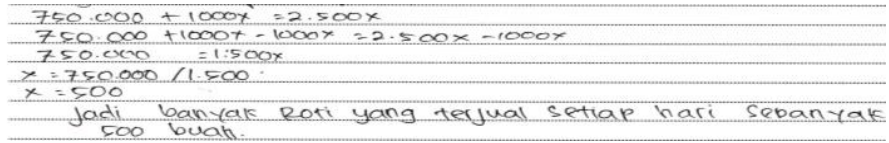

\section{Gambar 6}

Berdasarkan analisis hasil tes dan wawancara dari Gambar 6 subjek 2 menyelesaikan masalah dengan menambahakan suatu bilangan ke masing-masing ruas selanjutnya menyederhanakan variabel sehingga memperoleh suatu penyelesaiaan. Selanjutnya subjek 2 membuat dan menuliskan kesimpulan sesuai apa yang ditanyakan. Sehingga subjek 2 tergolong mampu mengoperasikan simbol-simbol matematika untuk menyelesaikan masalah persamaan linier satu variabel.

Berdasarkan uraian diatas sesuai dengan penelitian Widjajanti bahwa siswa dalam menyelesaikan masalah akan mampu mengambil keputusan, terampil mengumpulkan informasi yang relevan, menganalisis informasi dan menyedari betapa pentingnya meneliti hasil yang telah diperoleh (Widjajanti, 2009).

\section{Subjek 3 (Kategori Kemampuan Sedang)}

Berdasarkan analisis data tes dan hasil wawancara subjek 3 akan diuraikan pembahasan pada setiap langkah penyelesaian masalah matematika melalui pendekatan MEA sebagai berikut.
a. Tahap Identifikasi
Perbedaan antara
Current State dan Goal
State

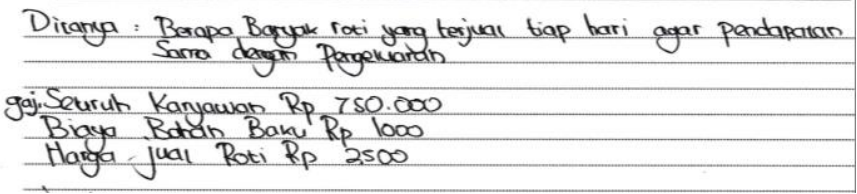

\section{Gambar 7}

Berdasarkan analisis hasil tes dan wawancara dari Gambar 7 subjek 3 mampu mengidentifikasi apa yang diketahui dan apa yang ditnyakan namun kurang sisitematis dalam melakukan penulisan. Sehingga subjek 3 tergolong mampu mengidentifikasi, menentukan dan memahami informasi penting dari permasalahan. 
b. Tahap Organisasi Sub Goals

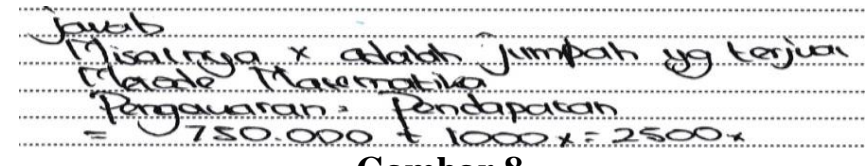

Gambar 8

Berdasarkan analisis hasil tes dan wawancara dari Gambar 8 subjek 3 membuat permisalan namun dalam menuliskan masih kurang tepat, subjek 3 juga mampu membuat model matematika dari permasalahan. Sehingga subjek 3 tergolong kurang tepat melakukan abstraksi dan menerjemahkan masalah persamaan linier satu variabel ke dalam kalimat/model matematika.

c. Tahap Pemilihan Operator atau Solusi

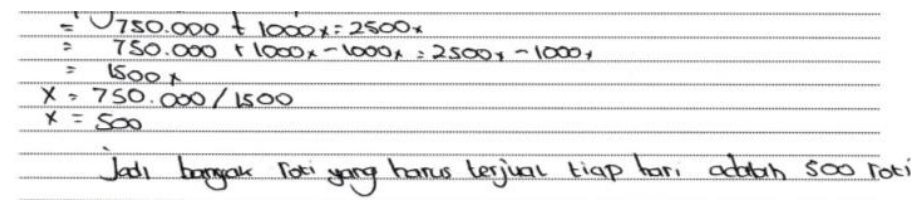

Gambar 9

Berdasarkan analisis hasil tes dan wawancara dari Gambar 9 subjek 3 dapat menyelesaikan masalah dengan menambahkan suatu bilangan ke masing-masing ruas selanjutnya menyederhanakan sehingga memperoleh jawaban. Selanjutnya subjek 3 membuat kesimpulan meskipun kalimatnya belum tepat sesuai apa yang ditanyakan. Sehingga subjek 3 tergolong mampu mengoperasikan simbol-simbol matematika untuk menyelesaikan masalah persamaan linier satu variabel.

Berdasarkan uraian tersebut sesuai dengan penelitian Widjajanti bahwa seseorang dalam menyelesaikan masalah mengalami kendala salah interprestasi yang disebabkan karena kerancuan bahasa yang digunakan serta kurang tepat dalam penggunaan istilah dalam merepresentasikan jawabannya (Widjajanti, 2009).

4. Subjek 4 (Kategori Kemampuan Sedang)

Berdasarkan analisis data tes dan hasil wawancara subjek 4 akan diuraikan pembahasan pada setiap langkah penyelesaian masalah matematika melalui pendekatan model MEA sebagai berikut.

a. Tahap Identifikasi Perbedaan antara Current State dan Goal State

\begin{tabular}{|c|}
\hline meneagi kariy awonny $a=$ Rp 750.000 .00 \\
\hline Biaya bahan baku= 1000.00 \\
\hline Harga jual Sebuak roti $=2,500,00$ \\
\hline Difonya: Berapa banyak roti yane hanus terival friaphariagar pendapton \\
\hline
\end{tabular}

Gambar 10

Berdasarkan analisis hasil tes dan wawancara dari Gambar 10 subjek 4 mampu menuliskan apa yang diketahui dan apa yang ditanyakan sesuai isi soal. Sehingga subjek 4 tergolong mampu mengidentifikasi, menentukan dan memahami informasi penting dari permasalahan

b. Tahap Organisasi Sub Goals

Dijamab $75000000+1000 x=2500 x$

\section{Gambar 11}

Berdasarkan analisis hasil tes dan wawancara dari Gambar 11 subjek 4 tidak membuat permisalan dan menuliskan model matematika langsung pada jawaban akhir tanpa menuliskan langkah-langkah yang sistematis. Sehingga subjek 4 belum mampu melakukan abstraksi dan menerjemahkan masalah persamaan linier satu variabel ke dalam kalimat/model matematika.

c. Tahap Pemilihan Operator atau Solusi

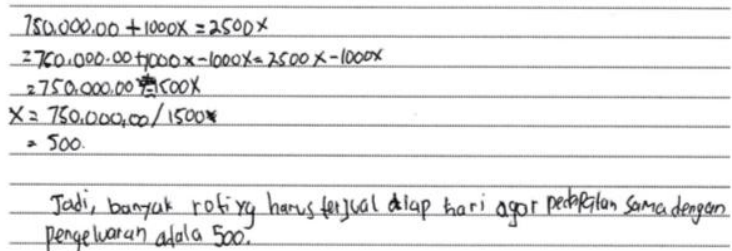

Gambar 12 
Berdasarkan analisis hasil tes dan wawancara dari Gambar 12 subjek 4 dapat menyelesaikan masalah dengan menambahkan suatu bilangan ke masing-masing ruas dan menyederhanakan variabel yang dicari serta mampu menuliskan kesimpulan dengan tepat sesuai apa yang ditanyakan pada soal. Sehingga subjek 4 tergolong mampu mengoperasikan simbol-simbol matematika untuk menyelesaikan masalah persamaan linier satu variabel.

Berdasrkan uraian diatas sesuai dengan penelitian Ayu Yarmayani bahwa subjek dalam menyelesaikan soal mampu menuliskan apa yang diketahui dan apa yang ditanyakan namun subjek tidak sistematis dan belum tepat menuliskan langkah penyelesaian soal tersebut (Yarmayani, 2016).

\section{Subjek 5 (Kategori Kemampuan Rendah)}

Berdasarkan analisis data tes dan hasil wawancara subjek 5 akan diuraikan pembahasan pada setiap langkah penyelesaian masalah matematika melalui pendekatan model MEA sebagai berikut.
a. Tahap Identifikasi Perbedaan
Mengali kariaw an $=750.000$
Bahan baku buat roti $\quad 1000$
Haraa jual roti:2500
antara Current State dan Goal State

Gambar 13

Berdasarkan analisis hasil tes dan wawancara dari Gambar 13 subjek 5 hanya menuliskan apa yang diketahui dan tidak menuliskan apa yang ditanyakan. Sehingga subjek 5 tergolong mampu mengidentifikasi dan menentukan apa yang diketahui namun belum memahami informasi penting dari permasalahan.

b. Tahap Organisasi Sub Goals

\section{Misolnya r a dalah jumlan roti \\ Gambar 14}

Berdasarkan analisis hasil tes dan wawancara dari Gambar 14 subjek 5 membuat permisalan dan model matematikadari permasalahan namun melewatkan langkah-langkah dalam dalam membentuk model matematika tersebut. Sehingga subjek 5 kurang tepat dalam melakukan abstraksi dan menerjemahkan masalah persamaan linier satu variabel ke dalam kalimat/model matematika.

\section{c. Tahap Pemilihan Operator atau Solusi}

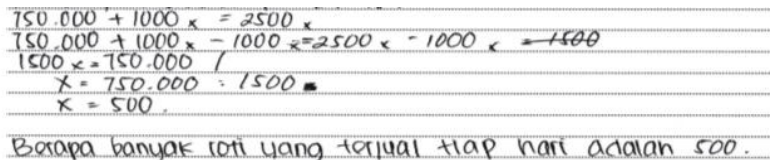

Gambar 15

Berdasarkan analisis hasil tes dan wawancara dari Gambar 15 subjek 5 dapat menyelesaikan masalah persamaan linier satu variabel meskipun dalam menuliskan simbol operasi matematika ada yang kurang tepat serta menuliskan kesimpulan meskipun belum tepat sesuai apa yang ditanyakan. Sehingga subjek 5 belum mampu mengoperasikan simbolsimbol matematika untuk menyelesaikan masalah persamaan linier satu variabel dengan tepat.

Berdasarkan uraian tersebut sesuai pada penelitian Irwitadia Hasibuan bahwa siswa dalam menyelesaikan masalah bentuk aljabar tidak mampu menganalisis soal cerita sehingga kebingungan mengartikan maksud soal. Oleh karenanya menyebabkan siswa tidak mampu menerjemahkan soal dengan baik (Hasibuan, 2015).

\section{Subjek 6 (Kategori Kemampuan Rendah)}

Berdasarkan analisis data tes dan hasil wawancara subjek 6 akan diuraikan pembahasan pada setiap langkah penyelesaian masalah matematika melalui pendekatan model MEA sebagai berikut.

a. Tahap Identifikasi Perbedaan antara Current State dan Goal State

$\begin{aligned} \text { Di ketahui }= & \text { Menggaj! kariawan }=750 \cdot 000 \\ & \text { bahan baku membuat roti }=1000 \\ & \text { Harga Setiap jual roti }=2500\end{aligned}$

\section{Gambar 16}

Berdasarkan analisis hasil tes dan wawancara dari Gambar 16 subjek 6 mampu mengidentifikasi apa yang diketahui namun tidak menuliskan apa yang ditanyakan dari soal. Sehingga subjek 6 tergolong mampu mengidentifikasi dan menentukan apa yang diketahui namun belum memahami informasi penting dari permasalahan dengan baik. 
b. Tahap Organisasi Sub Goals

Misalnya $x$ adalah jumlah roti
$-750.000+1000 x=2500 x$

Gambar 17

Berdasarkan analisis hasil tes dan wawancara dari Gambar 17 subjek 6 membuat permisalan namun kurang tepat dalam menuliskan model matematika dari permasalahan. Sehingga subjek 6 kurang tepat dalam kurang tepat melakukan abstraksi dan menerjemahkan masalah persamaan linier satu variabel ke dalam kalimat/model matematika.

c. Tahap Pemilihan Operator atau Solusi $=750 \cdot 000+1000 \times 2500$

$750 \cdot 000+1000 x=2500 x$
$750 \cdot 000+1000 x-1000 \times 2500 x-1000 x=$
$x=750 \cdot 000 / 1500$
$=500$

\section{Gambar 18}

Berdasarkan analisis hasil tes dan wawancara dari Gambar 18 subjek 6 mampu menyelesaikan permasalahan namun kurang tepat dalam menuliskan simbol operasi matematika dan tidak membuat kesimpulan dari permasalahan yang telah diselesaikan. Sehingga subjek 6 belum mampu mengoperasikan simbol-simbol matematika untuk menyelesaikan masalah persamaan linier satu variabel dengan tepat.

Berdasarkan uraian tersebut sesuai dengan penelitian Elita Safitri bahwa siswa dengan kemampuan rendah dapat menyebutkan informasi yang diketahui namun belum menguasai materi-materi prasyarat dan siswa kurang cermat serta teliti dalam merencanakan dan menyelesaikan masalah. Hal tersebut disebabkan siswa belum memahami konsep pada materi tersebut dengan baik (Safitri, 2016).

\section{SIMPULAN}

Berdasarkan paparan dan pembahasan hasil penelitian maka simpulan hasil penelitian analisis kemampuan penyelesaian masalah matematika siswa SMP melalui pendekatan MEA adalah Siswa kemampuan tinggi dalam menyelesaikan masalah matematika mampu mengidentifikasi dan memahami informasi penting dari permasalahan, mampu melakukan abstraksi ke dalam model matematika dan terampil mengoperasikan simbol-simbol matematika serta mampu membuat kesimpulan dengan tepat. Siswa menuliskan langkah-langkah penyelesaian dengan sistematis dan rinci.

Siswa kemampuan sedang dalam menyelesaikan masalah matematika mampu mengidentifikasi dan memahami informasi penting dari permasalahan dan terampil menyelesaikan masalah namun dalam menuliskan langkah-langkah penyelesaian kurang sistematis dan kurang rinci.

Siswa kemampuan rendah dalam menyelesaikan masalah matematika kurang terampil mengoperasikan simbol-simbol matematika serta tidak membuat kesimpulan dan menuliskan langkahlangkah penyelesaian kurang sistematis dan tidak rinci.

\section{DAFTAR PUSTAKA}

Delphie, B. (2009). Matematika Untuk Anak Berkebutuhan Khusus. Sleman: PT Intan Sejati Klaten.

Eviliyanida, E. (2010). Pemecahan Masalah Matematika. Jurnal Visipena, I, 10-17.

Hartini, T. I., \& Lianti, M. (2015). Pengaruh Penerapan Model Pembelajaran Means Ends Analysis ( MEA ) Terhadap Hasil Belajar Fisika. Jurnal Fisika Dan Pendidikan Fisika, 1(1).

Hasibuan, I. (2015). Hasil Belajar Siswa Pada Materi Bentuk Aljabar di Kelas VII SMP Negeri 1 Banda Aceh Tahun Pelajaran 2013/2014. Jurnal Peluang, 4, 5-11.

Juanda, M., Johar, R., \& Ikhsan, M. (2013). Peningkatan Kemampuan Pemecahan Masalah dan Komunikasi Matematis Siswa SMP Melalui Model Pembelajaran Kooperatif Tipe Think Pair Share (TPS). JurnalPeluang, 1(April), 81-92.

Kemendikbud, K. Guru Pembelajar Modul Matematika SMP Karakteristik Siswa SMP dan Bilangan (2016). Jakarta.

Muin, A., Permata, C., \& Afidah, A. (2014). The Achievement of Mathematical Connection Skill Based on Cognitive Level Through Means Ends Analysis (MEA) Strategy of Learning. Proceeding of International Conference On Research, Implementation And Education Of Mathematics And Sciences 2014, 4, 21-32. 
Nugroho, J. S., Mahfud, H., \& Karsono, K. (2017). Penerapan Model Means Ends Analysis (MEA) Untuk Meningkatkan Kemampuan Menyelesaikan Soal Ceritamata Pelajaran Matematika Pada Siswa Sekolah Dasar. Didaktika Dwija Indria, 5(1), 1-4.

Palupi, H. R. (2016). Keefektifan Model Pembelajaran Means-Ends Analysis pada Kemampuan Pemecahan Masalah Siswa Materi Segiempat. Unnes Journal of Mathematics Education, 5(2).

Permendiknas, P. Peraturan Menteri Pendidikan Nasional Republik Indonesia Nomor 22 Tahun 2006, Pub. L. No. 22, 1 (2006). Indonesia.

Riana, A. A., \& Abdulkarim, A. (2017). Application of Means Ends Analysis ( MEA ) Learning Model in Attempt to Improve Student' s High Order Thinking. International Journal Pedagogy of Sosial Studies, 2(1).

Safitri, E. (2016). Analisis Kemampuan Pemecahan Masalah Matematika Siswa berdasarkan Taksonomi Solo. Universitas Muhammadiyah Surakarta.

Supendi, A., Jamiah, Y., \& Ahmad, D. (2017). Model Means Ends Analysis dan Direct Intruction terhadap Kemampuan Pemecahan Masalah Matematis Siswa. Jurnal Pendidikan Dan Pembelajaran, 6(2), 1-10.

Suyatno, S. (2009). Menjelajah Pembelajaran Invovatif. Sidoarjo: Masmedia Buana Pustaka.

Triyanti, T. (2017). Pengaruh Penggunaan Model Pembelajaran Means- Ends Analysis Terhadap Peningkatan Kemampuan Pemecahan Masalah Matematis dan Productive Disposition Siswa SMP. Universitas Pasundan.

Widjajanti, D. B. (2009). Kemampuan pemecahan Masalah Matematis Mahasiswa Calon Guru Matematika: Apa dan Bagaimana Mengembangkannya. In Seminar Nasional Matematika dan Pendidikan Matematika (pp. 978-979). Yogyakarta.

Yahyawati, D. (2013). Penerapan Model Pembelajaran Means Ends Analysis Untuk Meningkatkan Kemampuan Siswa Dalam Pemecahan Masalah Matematika. UNIVERSITAS MUHAMMADIYAH SURAKARTA.

Yarmayani, A. (2016). Analisis Kemampuan Pemecahan Masalah Matematis Siswa Kelas XI MIPA SMA Negeri 1 Kota Jambi. Jurnal Ilmiah DIKDAYA, 6(2), 12-19. 